\title{
PHOSPHORUS FORMS IN SOME GRASSLAND SOILS IN WIELKOPOLSKA REGION: CHARACTERISATION AND AVAILABILITY FOR PLANTS
}

\author{
FORMY FOSFORU W WYBRANYCH GLEBACH ŁĄKOWYCH WIELKOPOLSKI: \\ CHARAKTERYSTYKA I PRZYSWAJALNOŚĆ PRZEZ ROŚLINY
}

\begin{abstract}
Summary. Phosphorus is an essential element for plant growth. The evaluation of available forms of this nutrient in soils used in agricultural productivity is demanded. The study assesses the amounts of phosphorus in different forms in surface horizon of Gleysols and Histosols used as meadow and pastures. Soil samples were collected from eight profiles situated in the eastern part of Wielkopolska in the Kujawskie Lake region, central Poland. Phosphorus forms were sequentially extracted by Hedley et al. (1982) procedure modified by Ajiboye et al. (2004). Moreover, total and available contents of phosphorus were determined. On the basis of the obtained results it was stated that the content of both total and available phosphorus was comparable for Gleysols and Histosols and on average amounted from 0.885 to $0.908 \mathrm{~g} \cdot \mathrm{kg}^{-1}$ for phosphorus total and from 0.220 to $0.276 \mathrm{~g} \cdot \mathrm{kg}^{-1}$ for the available form. The predominant extractable fractions were residual $\left(58 \%\right.$ of $\left.\mathrm{P}_{\text {tot }}\right)$ in Gleysols and organically bound $\left(49 \%\right.$ of $\left.\mathrm{P}_{\mathrm{tot}}\right)$ in Histosols. The percentage share of phosphorus in fraction I $(0.7 \%$ ), fraction II (from 19 to $25 \%$ ) and fraction IV (from 1.1 to $1.3 \%$ ) in total content of phosphorus was similar for Gleysols and Histosols. The correlation coefficients indicated that the content of organic matter, the amounts of total and available phosphorus strongly influenced water soluble phosphorus in the investigated soils.
\end{abstract}

Key words: phosphorus, Gleysols, Histosols, available forms, sequential extraction

\section{Introduction}

Phosphorus, besides nitrogen, potassium, sulphur and magnesium, is one of the macronutrients needed by all plants, because it is a component of nucleic acids, the phospholipids that compose cellular membranes, ATP and ADP molecules (Fuentes et al., 
Jakubus, M. (2015). Phosphorus forms in some grassland soils in Wielkopolska region: characterisation and availability for plants. Nauka Przyr. Technol., 9, 2, \#16. DOI: 10.17306/J.NPT.2015.2.16

2006). With reference to this, inputs of phosphorus are necessary to maintain profitable crop production. Soil phosphorus exists in various chemical forms, including inorganic and organic, which differ widely in their behaviour and fate in soils. Soils generally contain between 100 and $3000 \mathrm{mg}$ P per $1 \mathrm{~kg}$ of soil and ca. $15-80 \%$ of which is present in organic forms (Chen et al., 2008). Majority of studies concerning soils include only total content of phosphorus without consideration of its availability for plants. However, the total content of this element does not provide information on its potential mobility in the environment (Jakubus, 2012). Much greater practical importance is attributed to the identification of chemical forms of elements in soils, facilitating an assessment of the degree of their solubility, and thus their bioavailability.

Phosphorus availability to plants is controlled by several factors connected with soil properties as soil reaction, sorption, precipitation with iron, aluminium and calcium (Addiscott and Thomas, 2000; Khan and Joergensen, 2009; Malik et al., 2012). Sequential extraction methods are frequently used to evaluation of various forms of inorganic and organic phosphorus based on their solubility (Tyler, 2002). According to Schlichting et al. (2002), knowledge of the phosphorus chemistry in soils is important to evaluate possible effects of management (e.g. effect of induced degradation on nutrient status and its availability for plants). So far, majority of investigations connected with phosphorus fractionation have been performed on arable fertilized soil. Therefore, the objectives of the presents study were: 1) to determine content of total and available phosphorus, as well as its speciation in surface horizons of grassland soils by the sequential extraction procedure according to Hedley et al. (1982) and 2) to investigate the influence of chosen soil factors on phosphorus forms.

\section{Materials and methods}

\section{Soil samples and study area}

The area of the investigations from which soil samples were collected was situated in the eastern part of Wielkopolska in the Kujawskie Lake region extending between $52^{\circ} 30^{\prime} 20^{\prime \prime}$ and $52^{\circ} 30^{\prime} 02^{\prime \prime} \mathrm{N}$ latitude and 18 $30^{\prime} 03^{\prime \prime}$ and $18^{\circ} 32^{\prime} 28^{\prime \prime} \mathrm{E}$ longitude. Soils on the study area were classified according to WRB (World reference base..., 2006) as Gleysols and Histosols (Table 1) and were used as meadows and pastures. Soil samples $(\mathrm{n}=3)$ were collected from surface horizons (from 15 to $30 \mathrm{~cm}$ ) of eight soil profiles (Fig. 1). After drying at room temperature, soil samples were sieved through a $2 \mathrm{~mm}$ mesh sieve.

\section{Soil analyses}

Basic soil physico-chemical properties were determined using methods commonly applied in agro-chemical analytics. Soil reaction in $1 \mathrm{~mol} \cdot \mathrm{dm}^{-3} \mathrm{KCl}$ measured potentiometrically and organic matter (OM) content by loss-on-ignition were determined (Jakubus, 2010). Oxidizable organic carbon $\left(\mathrm{C}_{\text {tot }}\right)$ was determined using Vario Max CNS.

Total phosphorus of soils $\left(\mathrm{P}_{\text {tot }}\right)$ was assessed colorimetrically using the molybdate-blue method (Murphy and Riley, 1962) after $1 \mathrm{~g}$ of samples was incinerated at $550^{\circ} \mathrm{C}$ 
Jakubus, M. (2015). Phosphorus forms in some grassland soils in Wielkopolska region: characterisation and availability for plants. Nauka Przyr. Technol., 9, 2, \#16. DOI: 10.17306/J.NPT.2015.2.16

Table 1. Diagnostic horizons and nomenclature of soils according to World reference base... (2006)

Tabela 1. Poziomy diagnostyczne i nazewnictwo gleb według World reference base... (2006)

\begin{tabular}{|c|c|c|}
\hline $\begin{array}{c}\text { Profile number } \\
\text { Numer profilu }\end{array}$ & $\begin{array}{c}\text { Diagnostic horizon } \\
\text { Poziom diagnostyczny }\end{array}$ & WRB \\
\hline $1-4$ & Mollic & Mollic Gleysol \\
$5-8$ & Histic & Sapric Histosol \\
\hline
\end{tabular}

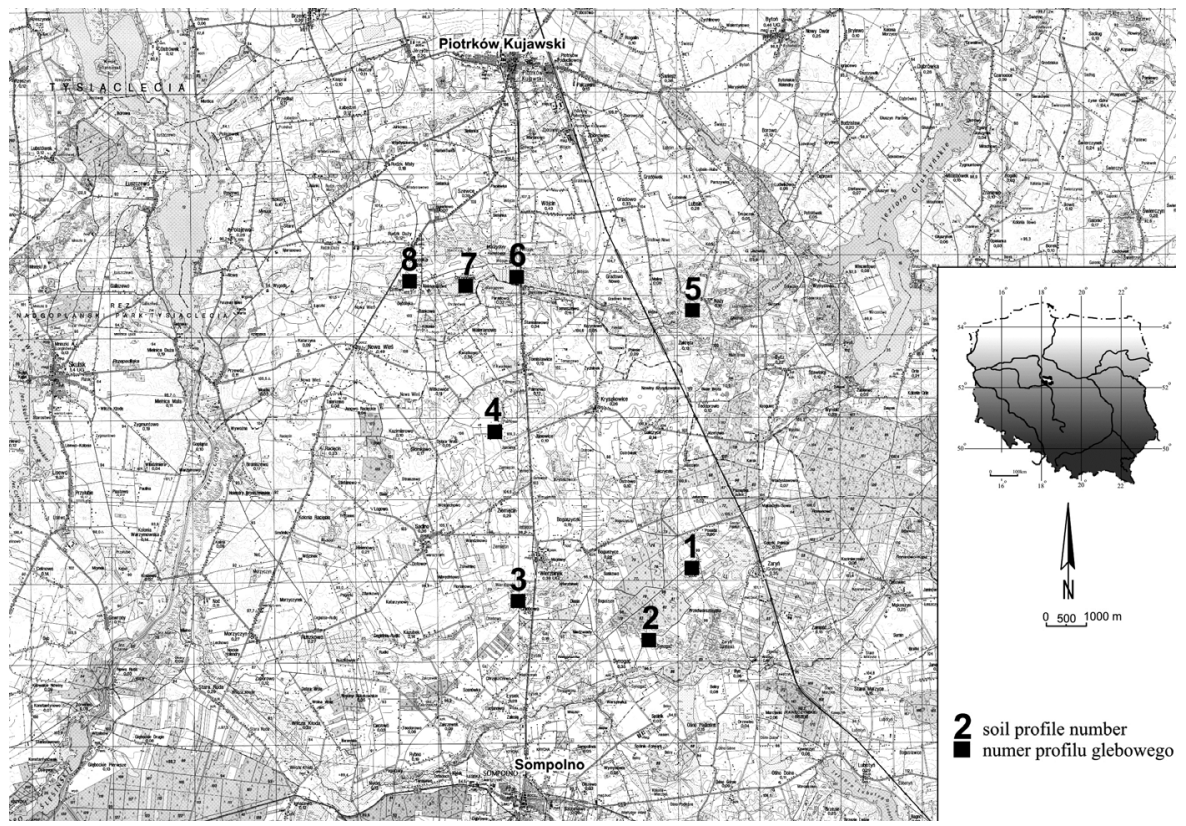

Fig. 1. Area of study

Rys. 1. Obszar badań

for $3 \mathrm{~h}$. Then $5 \mathrm{~cm}^{3}$ of concentrated $\mathrm{HCl}$ was added to the ash and the mixture was heated for $30 \mathrm{~min}$ at $180^{\circ} \mathrm{C}$. The amounts of phosphorus available for plants $\left(\mathrm{P}_{\mathrm{a}}\right)$ was obtained by procedure described by Sapek and Sapek (1997).

Soil samples were subjected to sequential phosphorus fractionation using a modified version of the Hedley et al. (1982) procedure as described by Ajiboye et al. (2004). Extraction was performed sequentially using deionized water (Fr. I), $0.5 \mathrm{~mol} \cdot \mathrm{dm}^{-3}$ $\mathrm{NaHCO}_{3}$ (pH 8.5) (Fr. II), $0.1 \mathrm{~mol} \cdot \mathrm{dm}^{-3} \mathrm{NaOH}$ (Fr. III) and $1 \mathrm{~mol} \cdot \mathrm{dm}^{-3} \mathrm{HCl}$ (Fr. IV) (Table 2). A $0.5 \mathrm{~g}$ (on an oven-dry basis) sample of analysed soils were weighed into $30 \mathrm{~cm}^{3}$ of extractant inside a $50 \mathrm{~cm}^{3}$ centrifuge tubes and shaken for $5 \mathrm{~h}$ at room temperature. Then the samples were left overnight and next day were shaken for $3 \mathrm{~h}$ at room temperature. The suspensions were centrifuged for $10 \mathrm{~min}$ at $8000 \mathrm{rpm}$ and filtered. A portion of $\mathrm{NaHCO}_{3}$ and $\mathrm{NaOH}$ extracts was acidified to precipitate extracted 
Jakubus, M. (2015). Phosphorus forms in some grassland soils in Wielkopolska region: characterisation and availability for plants. Nauka Przyr. Technol., 9, 2, \#16. DOI: 10.17306/J.NPT.2015.2.16

Table 2. Sequential extraction procedure

Tabela 2. Metoda ekstrakcji sekwencyjnej

\begin{tabular}{|c|c|c|c|}
\hline \multirow{2}{*}{$\begin{array}{l}\text { Fraction of phosphorus } \\
\text { Frakcja fosforu }\end{array}$} & \multirow{2}{*}{$\begin{array}{l}\text { Reagent } \\
\text { Odczynnik }\end{array}$} & \multicolumn{2}{|c|}{$\begin{array}{l}\text { Extraction conditions } \\
\text { Warunki ekstrakcji }\end{array}$} \\
\hline & & $\begin{array}{l}\text { time } \\
\text { czas } \\
\text { (h) }\end{array}$ & $\begin{array}{c}\text { temperature } \\
\text { temperatura } \\
\left({ }^{\circ} \mathrm{C}\right)\end{array}$ \\
\hline $\begin{array}{l}\text { I - water soluble phosphorus } \\
\text { fosfor wodnorozpuszczalny }\end{array}$ & $\mathrm{H}_{2} \mathrm{O}$ & 5.3 & $20-25$ \\
\hline $\begin{array}{l}\text { II - phosphorus associated with } \mathrm{Al} \text { and } \mathrm{Fe} \text { oxides } \\
\text { fosfor połączony z tlenkami } \mathrm{Al} \text { i Fe }\end{array}$ & $\begin{array}{l}0.5 \mathrm{~mol} \cdot \mathrm{dm}^{-3} \mathrm{NaHCO}_{3} \\
(\mathrm{pH} 8.2)\end{array}$ & 5.3 & $20-25$ \\
\hline $\begin{array}{l}\text { III - phosphorus associated with organic matter } \\
\text { fosfor połączony z materią organiczną }\end{array}$ & $0.1 \mathrm{~mol} \cdot \mathrm{dm}^{-3} \mathrm{NaOH}$ & 5.3 & $20-25$ \\
\hline $\begin{array}{l}\text { IV - phosphorus associated with } \mathrm{Ca} \\
\text { fosfor połączony } \mathrm{z} \mathrm{Ca}\end{array}$ & $1 \mathrm{~mol} \cdot \mathrm{dm}^{-3} \mathrm{HCl}$ & 5.3 & $60-70$ \\
\hline $\begin{aligned} \mathrm{V} \text { - } & \text { residual phosphorus } \\
& \text { fosfor pozostałościowy }\end{aligned}$ & - & - & - \\
\hline
\end{tabular}

organic matter and supernatant analysed for inorganic phosphorus $\left(\mathrm{P}_{\mathrm{i}}\right)$. A portion of $\mathrm{NaHCO}_{3}$ and $\mathrm{NaOH}$ extracts was analysed for total phosphorus fraction. For this purpose $10 \mathrm{~cm}^{3}$ of extractants were digested with $30 \% \mathrm{H}_{2} \mathrm{O}_{2}$ at $80^{\circ} \mathrm{C}$ for $2-3 \mathrm{~h}$ and then the whole was evaporated until dryness. A residue was dissolved in $3 \mathrm{~mol} \cdot \mathrm{dm}^{-3} \mathrm{HCl}$. The amount of organic phosphorus $\left(\mathrm{P}_{\mathrm{o}}\right)$ in fractions II and III was calculated by subtracting the value of $\mathrm{P}_{\mathrm{i}}$ from $\mathrm{P}_{\text {tot }}$. The phosphorus concentration in all extracts was determined colorimetrically using the molybdate-blue method (Murphy and Riley, 1962) on spectrophotometer at a wavelength of $720 \mathrm{~nm}$.

The phosphorus in residual fraction of soils was calculated by subtracting the sum of all the phosphorus fractions from the total content of the phosphorus.

Analyses of soil samples were carried out in three replicates and the presented data are the mean. The obtained data were subjected to statistical analysis employing the correlation coefficients.

\section{Results and discussion}

Selected properties of the investigated soils are presented in Table 3. Irrespective of the investigated soil, the soil reaction was alkali. The samples of Histosols contained on average more $\mathrm{C}_{\text {tot }}$ (mean $228.16 \mathrm{~g} \cdot \mathrm{kg}^{-1}$ ) and OM (mean $515.25 \mathrm{~g} \cdot \mathrm{kg}^{-1}$ ) than the soils of Gleysols (mean for $\mathrm{C}_{\text {tot }}-94.92 \mathrm{~g} \cdot \mathrm{kg}^{-1}$ and for $\mathrm{OM}-228.08 \mathrm{~g} \cdot \mathrm{kg}^{-1}$ ) (Table 3). This is explained by a higher degree of organic substance humification in Gleysols. Table 3 shows that mean values of total phosphorus ranged from $0.650 \mathrm{~g} \cdot \mathrm{kg}^{-1}$ (profile No. 7) to $1.190 \mathrm{~g} \cdot \mathrm{kg}^{-1}$ (profile No. 5) and the quantitative difference between these data was 2.0-fold. It is worth noticing that the amounts of total phosphorus in surface horizon of the investigated soils were representative for Polish conditions, what is consistent with the 
Jakubus, M. (2015). Phosphorus forms in some grassland soils in Wielkopolska region: characterisation and availability for plants. Nauka Przyr. Technol., 9, 2, \#16. DOI: 10.17306/J.NPT.2015.2.16

Table 3. Soil reaction, organic matter content, total carbon, total and available phosphorus $\left(\mathrm{g}^{\mathrm{kg}} \mathrm{kg}^{-1}\right)$ Tabela 3. Odczyn gleby, zawartość materii organicznej, węgiel ogólny, fosfor ogólny i przyswajalny $\left(\mathrm{g} \cdot \mathrm{kg}^{-1}\right)$

\begin{tabular}{|l|c|c|c|c|c|}
\hline $\begin{array}{l}\text { Profile number } \\
\text { Numer profilu }\end{array}$ & $\mathrm{pH}$ & $\mathrm{OM}-\mathrm{MO}$ & $\mathrm{C}_{\text {tot }}-\mathrm{C}_{\mathrm{og}}$ & $\mathrm{P}_{\text {tot }}-\mathrm{P}_{\mathrm{og}}$ & $\mathrm{P}_{\mathrm{a}}-\mathrm{P}_{\mathrm{p}}$ \\
\hline \multicolumn{5}{|c|}{ Gleysols } \\
\hline 1 & 7.3 & 244.33 & 49.59 & 0.92 & 0.33 \\
2 & 7.6 & 206.00 & 83.77 & 0.98 & 0.34 \\
3 & 7.5 & 194.00 & 82.86 & 0.79 & 0.03 \\
4 & 7.3 & 268.00 & 163.47 & 0.85 & 0.17 \\
\hline SD & - & 34.19 & 48.39 & 0.08 & 0.14 \\
\hline Mean- Średnio & - & 228.08 & 94.92 & 0.88 & 0.22 \\
\hline & & & Histosols & 1.19 & 0.11 \\
\hline 5 & 7.7 & 345.00 & 120.70 & 1.10 & 0.32 \\
6 & 7.2 & 713.00 & 328.36 & 0.65 & 0.37 \\
7 & 7.3 & 400.00 & 183.88 & 0.69 & 0.30 \\
\hline 8 & 6.5 & 584.00 & 279.69 & 0.27 & 0.11 \\
\hline SD & - & 163.29 & 93.46 & 0.91 & 0.28 \\
\hline Mean- Średnio & - & 515.25 & 228.16 & & \\
\hline
\end{tabular}

$\mathrm{C}_{\text {tot }}-$ total carbon, $\mathrm{OM}$ - organic matter, $\mathrm{P}_{\text {tot }}-$ total phosphorus, $\mathrm{P}_{\mathrm{a}}-$ available phosphorus.

$\mathrm{C}_{\mathrm{og}}$ - węgiel ogólny, $\mathrm{MO}$ - materia organiczna, $\mathrm{P}_{\mathrm{og}}$ - fosfor ogólny, $\mathrm{P}_{\mathrm{p}}$ - fosfor przyswajalny.

results of other authors (Gotkiewicz et al., 2006; Sammel and Niedźwiecki, 2006). Schlichting et al. (2002) found that top layer of Histosols is richer in total and available phosphorus than Gleysols. Neither total nor available content of nutrient were confirmed by the statement during the study. Moreover, the data presented at Table 3 testified that samples of Gleysols characterised on average the comparable level of $\mathrm{P}_{\text {tot }}$ $\left(0.908 \mathrm{~g} \cdot \mathrm{kg}^{-1}\right)$ and $\mathrm{P}_{\mathrm{a}}\left(0.276 \mathrm{~g} \cdot \mathrm{kg}^{-1}\right)$ as samples of Histosols $\left(0.885\right.$ and $0.220 \mathrm{~g} \cdot \mathrm{kg}^{-1}$ for $\mathrm{P}_{\text {tot }}$ and $\mathrm{P}_{\mathrm{a}}$, respectively). Regardless of this, significance difference (12 times) between minimum value $\left(0.032 \mathrm{~g} \cdot \mathrm{kg}^{-1}\right.$ in profile No. 3) and maximum $\left(0.368 \mathrm{~g} \cdot \mathrm{kg}^{-1}\right.$ in profile No. 7) values of available phosphorus was revealed (Table 3). Pawluczuk and Alberski (2011) investigated surface horizon of Histosols used as a grassland soil and they found similar amounts of available phosphorus as in the presented study. However, Gotkiewicz et al. (2006) assessed a higher level of $\mathrm{P}_{\mathrm{a}}$ in the examinated Histosols in comparison to the author's own studies where the contents of available form of nutrient in the analysed Histosols ranged between 0.114 and $0.368 \mathrm{~g} \cdot \mathrm{kg}^{-1}$ (Table 3).

Also Sammel and Niedźwiecki (2006) observed a considerable fluctuation of available phosphorus in soils of similar genesis. Ilnicki (2002) and Sapek (2011) maintained that quantity differentiation of nutrients depends on presence of organic matter and soil 
Jakubus, M. (2015). Phosphorus forms in some grassland soils in Wielkopolska region: characterisation and availability for plants. Nauka Przyr. Technol., 9, 2, \#16. DOI: 10.17306/J.NPT.2015.2.16

reaction. According to class abundance for available phosphorus prepared for organic soils (Sapek and Sapek, 1997) top layers of the investigated soils characterised medium and very low content of available forms of nutrient. Low and medium abundance of phosphorus available for plants in Gleysols and Histosols was also reported by Sammel and Niedźwiecki (2006) and Pietrzak (2012).

On the basis of the results it can be assumed that such soils should show phosphorus deficiency, thus a greater phosphorus turnover in soil depends on many different processes, such as e.g. precipitation, sorption, mineralization and leaching. Taking into account these factors identification of phosphorus in soils is a fundamental prerequisite to understanding nutrient dynamics in soil systems and the mechanisms responsible for the rate of release of potentially available forms of phosphorus for plants (Fuentes et al., 2006). Moreover, Szara and Sosulski (2012) stressed that it is necessary to monitor agricultural soils in terms of their susceptibility to phosphorus losses. The monitoring should focus on the level of available and active nutrient.

In the present study, four fractions (the fifth one is residual) of soils were separated using the modified Hedley's method. According to this method the pool of soil phosphorus is partitioned into soluble, aluminium/iron bound, organic bound, calcium bound and residual forms. Table 4 presents results referred to phosphorus quantitative changes in sequentially separated fractions. Phosphorus quantities in obtained fractions increased in the following succession: I $<$ IV $<$ II $<$ III $<$ V for surface diagnostic horizon of Gleysols. On the other hand, Histosols were characterised by an increase of the nutrient in the following sequence of fractions: I $<$ IV $<$ V $<$ II $<$ III (Table 4). Irrespective of the analysed soils, the highest concentrations of the inorganic phosphorus were found in the residual (V) fraction $\left(147.34-698.09 \mathrm{mg} \cdot \mathrm{kg}^{-1}\right)$, whereas the lowest contents of $\mathrm{P}_{\mathrm{i}}$ were obtained in soluble fraction (I) $\left(3.95-8.45 \mathrm{mg} \cdot \mathrm{kg}^{-1}\right)$ and calcium bound fraction (IV) $\left(3.77-20.34 \mathrm{mg} \cdot \mathrm{kg}^{-1}\right)$. The difference between minimum and maximum values of phosphorus content in mentioned fractions were 2.0 (fr. I) and 5.0 fold (fr. IV and V). The surface horizons from Gleysols contained higher proportions of residual phosphorus, however surface horizons of Histosols were richer in phosphorus of fractions II, III and IV. This kind of tendency was confirmed by literature (Schlichting et al., 2002).

The mean percentage share of phosphorus in the obtained fractions in its total content was similar for Gleysols and Histosols in fractions I (0.7\%), II (from 19 to 25\%) and IV (from 1.1 to $1.3 \%$ ) (Fig. 2). Taking into consideration that water soluble phosphorus (fr. I) is an easily available, nutrient for plants and at the same time may undergo different transformation, such a small portion is disadvantageous.

A significant difference was found for III and V fractions of the investigated soils. Histosols were characterised by a higher share of phosphorus in organic bound fraction $(49 \%)$ and lower in residual one (24\%) in comparison to the data assessed for Gleysols ( $21 \%$ and $58 \%$ for fractions III and V, respectively). Comparable levels of water soluble phosphorus and organically bound phosphorus in grassland soils were revealed by McDowell and Condron (2000).

It is evident from the data presented in Table 4 that the total, inorganic and organic phosphorus in fractions II and III oscillated in a wide range because the differences between extreme values were 3.0-18.0 fold. Gleysols samples were characterised by a lower mean value of $P_{\text {tot }}$ in fractions II $\left(168.47 \mathrm{mg} \cdot \mathrm{kg}^{-1}\right)$ and III $\left(165.59 \mathrm{mg} \cdot \mathrm{kg}^{-1}\right)$, than Histosols (225.10 and $446.66 \mathrm{mg} \cdot \mathrm{kg}^{-1}$ in fractions II and III, respectively). The quantitative 
Jakubus, M. (2015). Phosphorus forms in some grassland soils in Wielkopolska region: characterisation and availability for plants. Nauka Przyr. Technol., 9, 2, \#16. DOI: 10.17306/J.NPT.2015.2.16

Table 4. Amounts of phosphorus in soil fractions $\left(\mathrm{mg} \cdot \mathrm{kg}^{-1}\right)$

Tabela 4. Ilości fosforu we frakcjach gleby $\left(\mathrm{mg} \cdot \mathrm{kg}^{-1}\right)$

\begin{tabular}{|c|c|c|c|c|c|c|c|c|c|}
\hline \multirow{3}{*}{$\begin{array}{c}\text { Profile } \\
\text { number } \\
\text { Numer } \\
\text { profilu }\end{array}$} & \multicolumn{9}{|c|}{ Fractions of phosphorus - Frakcje fosforu } \\
\hline & \multirow{2}{*}{$\mathrm{I}$} & \multicolumn{3}{|c|}{ II } & \multicolumn{3}{|c|}{ III } & \multirow{2}{*}{ IV } & \multirow{2}{*}{$\mathrm{V}$} \\
\hline & & $P_{\text {tot }}-P_{o g}$ & $\mathrm{P}_{\mathrm{i}}-\mathrm{P}_{\mathrm{n}}$ & $\mathrm{P}_{\mathrm{o}}$ & $\mathrm{P}_{\text {tot }}-\mathrm{P}_{\mathrm{og}}$ & $P_{i}-P_{n}$ & $\mathrm{P}_{\mathrm{o}}$ & & \\
\hline \multicolumn{10}{|c|}{ Gleysols } \\
\hline 1 & 8.31 & 151.88 & 67.85 & 84.03 & 175.14 & 77.20 & 97.94 & 3.77 & 580.89 \\
\hline 2 & 8.45 & 77.18 & 29.57 & 47.61 & 181.94 & 37.52 & 144.42 & 14.33 & 698.09 \\
\hline 3 & 4.49 & 155.71 & 43.98 & 111.73 & 131.85 & 35.42 & 96.44 & 6.97 & 490.97 \\
\hline 4 & 3.95 & 289.11 & 101.34 & 187.77 & 173.41 & 52.10 & 121.3 & 13.16 & 370.37 \\
\hline SD & 2.41 & 88.18 & 31.36 & 59.44 & 22.79 & 19.25 & 22.66 & 5.03 & 138.74 \\
\hline $\begin{array}{l}\text { Mean } \\
\text { Średnio }\end{array}$ & 6.30 & 168.47 & 60.69 & 107.79 & 165.59 & 50.56 & 115.03 & 9.56 & 535.08 \\
\hline \multicolumn{10}{|c|}{ Histosols } \\
\hline 5 & 7.29 & 139.79 & 48.50 & 91.29 & 770.45 & 119.22 & 651.23 & 8.87 & 263.59 \\
\hline 6 & 5.79 & 267.38 & 130.78 & 136.60 & 537.64 & 97.05 & 440.59 & 18.51 & 270.60 \\
\hline 7 & 5.43 & 223.30 & 57.57 & 165.73 & 253.59 & 63.87 & 189.72 & 20.34 & 147.34 \\
\hline 8 & 7.24 & 269.94 & 120.03 & 149.91 & 224.94 & 94.02 & 130.92 & 8.56 & 179.32 \\
\hline SD & 0.97 & 60.77 & 42.18 & 32.02 & 257.91 & 22.75 & 239.12 & 6.22 & 61.38 \\
\hline $\begin{array}{l}\text { Mean } \\
\text { Średnio }\end{array}$ & 6.44 & 225.10 & 89.22 & 135.88 & 446.66 & 93.54 & 353.12 & 14.07 & 215.21 \\
\hline
\end{tabular}

I - water soluble phosphorus, II - phosphorus associated with $\mathrm{Al}$ and Fe oxides, III - phosphorus associated with organic matter, IV - phosphorus associated with $\mathrm{Ca}, \mathrm{V}-$ residual phosphorus.

$\mathrm{P}_{\text {tot }}-$ total phosphorus, $\mathrm{P}_{\mathrm{i}}-$ inorganic phosphorus, $\mathrm{P}_{\mathrm{o}}-$ organic phosphorus.

I - fosfor wodnorozpuszczalny, II - fosfor połączony z tlenkami Al i Fe, III - fosfor połączony z materią organiczną, IV - fosfor połączony z $\mathrm{Ca}, \mathrm{V}$ - fosfor pozostałościowy.

$\mathrm{P}_{\mathrm{og}}-$ fosfor ogólny, $\mathrm{P}_{\mathrm{n}}-$ fosfor nieorganiczny, $\mathrm{P}_{\mathrm{o}}$ - fosfor organiczny.

level of mean values of $\mathrm{P}_{\mathrm{o}}$ was higher than $\mathrm{P}_{\mathrm{i}}$ in fractions II and III of investigated soils. Such a significant difference was found for fraction III of Histosols, where mean amount of $P_{o}\left(353.12 \mathrm{mg} \cdot \mathrm{kg}^{-1}\right)$ was almost 4.0 times higher than $P_{i}\left(93.54 \mathrm{mg} \cdot \mathrm{kg}^{-1}\right)$. The difference between mean contents of $P_{o}$ and $P_{i}$ in fraction III of Gleysols was 2.0 fold and values amounted $115.03 \mathrm{mg} \cdot \mathrm{kg}^{-1}$ and $50.56 \mathrm{mg} \cdot \mathrm{kg}^{-1}$, respectively. The results of McDowell and Condron (2000) studies corroborate with the obtained data in the author's own experiments. Lower differences between $\mathrm{P}_{\mathrm{o}}$ and $\mathrm{P}_{\mathrm{i}}$ amounts were found also for fraction II of the investigated soils. The data presented in Table 4 testified that mean content of $\mathrm{P}_{\mathrm{o}}$ was by $50 \%$ (Histosols) and $80 \%$ (Gleysols) higher than amounts of $\mathrm{P}_{\mathrm{i}}$ in fraction II. Schlichting et al. (2002) investigated P forms in Histosols and Gleysols by Hedley's sequential extraction procedure. The above researchers confirmed predominating share of organic phosphorus in fractions II and III of the analysed soils. Moreover, 
Jakubus, M. (2015). Phosphorus forms in some grassland soils in Wielkopolska region: characterisation and availability for plants. Nauka Przyr. Technol., 9, 2, \#16. DOI: 10.17306/J.NPT.2015.2.16

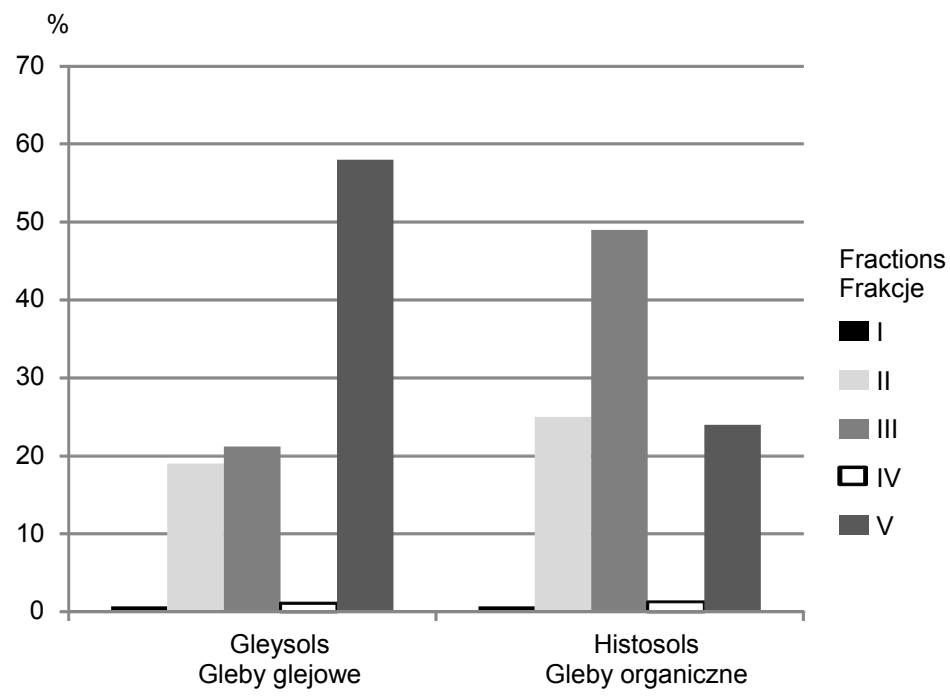

Fig. 2. Share of fractions of phosphorus in total phosphorus in Gleysols and Histosols

Rys. 2. Udział frakcji fosforu w fosforze ogólnym w glebach glejowych i organicznych

the cited studies confirmed that Histosols were more abundant in both organic and inorganic forms of nutrient in comparison to Gleysols.

According to literature data (McDowell and Condron, 2000; Schlichting et al., 2002) the amounts of phosphorus fractions are determined by the total phosphorus content and organic carbon in Gleysols and Histosols. This statement was only partly confirmed in the present study. The interdependencies between the amounts of phosphorus fractions and organic matter, total and available phosphorus were described by simple correlation coefficients in Table 5. The calculated correlation matrix was bigger for Histosols and, for the most part, the interdependencies were significant at the highest level of probability. It needs to be stressed that available phosphorus of Histosols had a strong influence on phosphorus fraction. Simultaneously such an interaction was not observed in Gleysols conditions. The organic matter content mainly affected the amounts of phosphorus fraction of Gleysols. The contents of inorganic and total forms of phosphorus fractions were mainly shaped by total content of nutrient in either Histosols or Gleysols. Regardless of the investigated soils, the influence of organic matter, phosphorus total and available on phosphorus level was observed only in the case of phosphorus fraction I. At the same time organic matter negatively affected the content of water soluble phosphorus and positively total and available phosphorus. 
Jakubus, M. (2015). Phosphorus forms in some grassland soils in Wielkopolska region: characterisation and availability for plants. Nauka Przyr. Technol., 9, 2, \#16. DOI: 10.17306/J.NPT.2015.2.16

Table 5. Simple correlation coefficient values between analysed forms of phosphorus and chosen soil parameters

Tabela 5. Wartości współczynników korelacji prostej między analizowanymi formami fosforu a wybranymi parametrami gleby

\begin{tabular}{|c|c|c|c|c|}
\hline \multirow{2}{*}{$\begin{array}{l}\text { Profile number } \\
\text { Numer profilu }\end{array}$} & \multirow{2}{*}{$\begin{array}{l}\text { Fraction of phosphorus } \\
\text { Frakcja fosforu }\end{array}$} & \multicolumn{3}{|c|}{ Soil parameters - Parametry gleby } \\
\hline & & $\mathrm{P}_{\mathrm{tot}}-\mathrm{P}_{\mathrm{og}}$ & $\mathrm{P}_{\mathrm{a}}-\mathrm{P}_{\mathrm{p}}$ & $\mathrm{OM}-\mathrm{MO}$ \\
\hline \multirow[t]{9}{*}{$1-4$} & I & $0.869^{* *}$ & $0.867 * *$ & $-0.617^{* *}$ \\
\hline & II $-P_{\text {tot }}-P_{o g}$ & $-0.560^{* *}$ & n.s. & $0.973^{* *}$ \\
\hline & II $-P_{i}-P_{n}$ & n.s. & n.s. & $0.894^{* *}$ \\
\hline & $\mathrm{II}-\mathrm{P}_{\mathrm{o}}$ & $-0.712^{* *}$ & $-0.619^{* *}$ & $0.800^{* *}$ \\
\hline & $\mathrm{III}-\mathrm{P}_{\mathrm{tot}}-\mathrm{P}_{\mathrm{og}}$ & n.s. & n.s. & $0.914^{* *}$ \\
\hline & III $-P_{i}-P_{n}$ & $0.659^{* *}$ & n.s. & n.s. \\
\hline & III $-\mathrm{P}_{\mathrm{o}}$ & n.s. & n.s. & n.s. \\
\hline & IV & n.s. & n.s. & n.s. \\
\hline & V & $0.680^{* *}$ & n.s. & $-0.920^{* *}$ \\
\hline \multirow[t]{9}{*}{$5-8$} & I & $0.976^{* *}$ & $0.962^{* *}$ & $-0.631^{* *}$ \\
\hline & $\mathrm{II}-\mathrm{P}_{\mathrm{tot}}-\mathrm{P}_{\mathrm{og}}$ & n.s. & $0.866^{* *}$ & $0.911^{* *}$ \\
\hline & II $-P_{i}-P_{n}$ & $-0.836^{* *}$ & $0.928^{* *}$ & n.s. \\
\hline & $\mathrm{II}-\mathrm{P}_{\mathrm{o}}$ & n.s. & $0.528^{* *}$ & $0.964^{* *}$ \\
\hline & $\mathrm{III}-\mathrm{P}_{\mathrm{tot}}-\mathrm{P}_{\mathrm{og}}$ & $0.917^{* *}$ & $-0.828^{* *}$ & n.s. \\
\hline & III $-P_{i}-P_{n}$ & $0.765^{* *}$ & $-0.846^{* *}$ & n.s. \\
\hline & III $-P_{o}$ & $0.912^{* *}$ & $0.828^{* *}$ & n.s. \\
\hline & IV & n.s. & $0.651^{* *}$ & n.s. \\
\hline & V & n.s. & n.s. & $0.804^{* *}$ \\
\hline
\end{tabular}

Explanation of fractions of phosphorus - as under Table 4.

$\mathrm{P}_{\text {tot }}-$ total phosphorus, $\mathrm{P}_{\mathrm{a}}$ - available phosphorus, $\mathrm{OM}$ - organic matter.

The statistically significant correlation coefficient values between chosen soil parameters and the content of phosphorus were designated by $* *$ for $\mathrm{p}<0.01 ;$ n.s. - not significant correlation.

Objaśnienie frakcji fosforu - jak pod tabelą 4 .

$\mathrm{P}_{\mathrm{og}}$ - fosfor ogólny, $\mathrm{P}_{\mathrm{p}}$ - fosfor przyswajalny, $\mathrm{MO}$ - materia organiczna.

Statystycznie istotne wartości współczynników korelacji między wybranymi parametrami gleby i zawartością fosforu zostały oznaczone przez ** dla $\mathrm{p}<0,01 ;$ n.s. - korelacja nieistotna.

\section{Conclusions}

1. The modified Hedley's fractionation appears to be a well suited and helpful method to study phosphorus in soils of different genesis.

2. The content of organic matter in Histosols was higher than in Gleysols; however, despite of this the amounts of total and available phosphorus were comparable. 
Jakubus, M. (2015). Phosphorus forms in some grassland soils in Wielkopolska region: characterisation and availability for plants. Nauka Przyr. Technol., 9, 2, \#16. DOI: 10.17306/J.NPT.2015.2.16

3. The contents of available and water soluble phosphorus in the investigated soils were very low indicating on potential phosphorus deficiency.

4. The predominat portion of phosphorus in Gleysols was obtained in residual fraction, while in Histosols a significant share of phosphorus was recorded in the form bound with organic matter.

\section{References}

Addiscott, T. M., Thomas, D. (2000). Tillage, mineralization and leaching: phosphate. Soil Till. Res., 53, 255-273.

Ajiboye, B., Akinremi, O. O., Racz, G. J. (2004). Laboratory characterization of phosphorus in fresh and oven-dried organic amendments. J. Environ. Qual., 22, 1062-1069.

Chen, C. R., Condron, L. M., Xu, Z. H. (2008). Impacts of grassland afforestation with coniferous trees on soil phosphorus dynamics and associated microbial processes: a review. For. Ecol. Manage., 255, 396-409.

Fuentes, B., Bolan, N., Naidu, R., de la Luz Mora, M. (2006). Phosphorus in organic waste - soil systems. J. Soil Sci. Plant. Nutr., 6, 2, 64-83.

Gotkiewicz, J., Pawluczuk, J., Piwowarska, M. (2006). Zawartość składników mineralnych w glebach gytiowo-murszowych obiektu Gązwa. Woda Środ. Obsz. Wiej., 6, 2, 18, 65-75.

Hedley, M. J., Stewart, W. B., Chauhan, B. S. (1982). Changes in inorganic and organic soil phosphorus fractions by cultivation practices and by laboratory incubations. Soil Sci. Soc. Am. J., 46, 970-976.

Ilnicki, P. (2002). Torfowiska i torf. Poznań: Wyd. AR.

Jakubus, M. (2010). Wybrane zagadnienia z gleboznawstwa i chemii rolnej. Poznań: Wyd. UP.

Jakubus, M. (2012). Evaluation of compost by selected chemical and biological methods. Fresen. Environ. Bull., 21, 11c, 3464-3472.

Khan, K. S., Joergensen, R. G. (2009). Changes in microbial biomass and P fractions in biogenic household waste compost amended with inorganic P fertilizers. Bioresour. Technol., 100, 303-309.

Malik, M. A., Marschner, P., Khan, K. S. (2012). Addition of organic and inorganic P sources to soil - effects on P pools and microorganisms. Soil Biol. Biochem., 49, 106-113.

McDowell, R. W., Condron, L. M. (2000). Chemical nature and potential mobility of phosphorus in fertilized grassland soils. Nutr. Cycl. Agroecosyst., 57, 225-233.

Murphy, J., Riley, J. P. (1962). A modified single solution method for determination of phosphate in natural water. Anal. Chim. Acta, 27, 31-36.

Pawluczuk, J., Alberski, J. (2011). Warunki siedliskowe i roślinność użytków zielonych na glebach torfowo-murszowych z terenu Pojezierza Olsztyńskiego. Woda Środ. Obsz. Wiej., 11, 3, $35,183-195$.

Pietrzak, S. (2012). Odczyn i zasobność gleb łąkowych w Polsce. Woda Środ. Obsz. Wiej., 12, 1, $37,105-117$.

Sammel, A., Niedźwiecki, E. (2006). Zawartość makro- i mikroelementów w glebach murszastych w obrębie Równiny Odrzańsko-Zalewowej. Woda Środ. Obsz. Wiej., 6, 2, 18, 293-304.

Sapek, B. (2011). Sorpcja fosforu przez mursze i utwory torfowe w rejonie doliny Biebrzy. Woda Środ. Obsz. Wiej., 11, 3, 35, 219-235.

Sapek, A., Sapek, B. (1997). Metody analizy chemicznej gleb organicznych. Mater. Instr. IMUZ, 11.

Schlichting, A., Leinweber, P., Meissner, R., Altermann, M. (2002). Sequentially extracted phosphorus fractions in peat-derived soils. J. Plant Nutr. Soil Sci., 165, 290-298. 
Jakubus, M. (2015). Phosphorus forms in some grassland soils in Wielkopolska region: characterisation and availability for plants. Nauka Przyr. Technol., 9, 2, \#16. DOI: 10.17306/J.NPT.2015.2.16

Szara, E., Sosulski, T. (2012). The use of phosphorus sorption parameters in the monitoring of potential emissions of this component from the arable lands. Soil Sci. Annu., 63, 3, 24-30.

Tyler, G. (2002). Phosphorus fractions in grassland soils. Chemosphere, 48, 343-349.

World reference base for soil resources 2006. (2006). World Soil Resour. Rep., 103.

\section{FORMY FOSFORU W WYBRANYCH GLEBACH ŁĄKOWYCH WIELKOPOLSKI: CHARAKTERYSTYKA I PRZYSWAJALNOŚĆ PRZEZ ROŚLINY}

Streszczenie. Fosfor jest niezbędnym dla roślin składnikiem pokarmowym. W glebach użytkowanych rolniczo w celach diagnostycznych określa się formy przyswajalne fosforu. W niniejszej pracy oznaczono ilości fosforu w różnych połączeniach z fazą stałą gleb klasyfikowanych jako Gleysols i Histosols, a użytkowanych jako łąki i pastwiska. Próbki glebowe do badań pobrano z wierzchniej warstwy ośmiu profili glebowych zlokalizowanych w centralnej Wielkopolsce na Pojezierzu Kujawskim. Formy fosforu określono, wykorzystując zmodyfikowaną metodę ekstrakcji sekwencyjnej według Hedleya i in. (1982). Ponadto w badanych glebach oznaczono ilości ogólne i przyswajalne fosforu. Na podstawie uzyskanych danych stwierdzono, że wierzchnia warstwa gleb organicznych (Histosols) i glejowych (Gleysols) charakteryzowała się zbliżonymi ilościami ogólnymi oraz przyswajalnymi fosforu. Zawartości ogólne fosforu wynosiły od 0,885 do $0,908 \mathrm{~g} \cdot \mathrm{kg}^{-1}$, a fosforu przyswajalnego - od 0,220 do $0,276 \mathrm{~g} \cdot \mathrm{kg}^{-1}$. Największy udział w stosunku do ogólnej ilości fosforu dotyczył składnika w związkach nieulegających ekstrakcji (58\%) oraz w połączeniach organicznych (49\%), co miało miejsce odpowiednio w odniesieniu do Gleysols i Histosols. Procentowy udział fosforu frakcji I (0,7\%), frakcji II (od 19 do 25\%) i frakcji IV (od 1,1 do 1,3\%) w ogólnej ilości fosforu był podobny dla Gleysols i Histosols. Na podstawie współczynników korelacji prostej stwierdzono, że ilość materii organicznej, zawartość fosforu ogółem i fosforu przyswajalnego silnie wpływały na ilości fosforu wodnorozpuszczalnego.

Słowa kluczowe: fosfor, Gleysols, Histosols, formy przyswajalne, ekstrakcja sekwencyjna

Corresponding address - Adres do korespondencji:

Monika Jakubus, Katedra Gleboznawstwa i Ochrony Gruntów, Uniwersytet Przyrodniczy w Poznaniu, ul. Szydlowska 50,60-656 Poznań, Poland, e-mail: monja@up.poznan.pl

Accepted for publication - Zaakceptowano do opublikowania:

28.10.2014

For citation - Do cytowania:

Jakubus, M. (2015). Phosphorus forms in some grassland soils in Wielkopolska region: characterisation and availability for plants. Nauka Przyr. Technol., 9, 2, \#16. DOI: 10.17306/J.NPT. 2015.2.16 